\title{
EFFECT OF CAPTOPRIL, A CONVERTING ENZYME INHIBITOR ON RENAL VASCULAR RESISTANCE IN PENTOBARBITAL ANESTHETIZED DOGS
}

\author{
Susumu SATOH, Susumu FUJISAWA*, Reiko TANAKA* \\ and Kengo NAKAI* \\ Department of Pharmacology, Pharmaceutical Institute, Tohoku University, \\ Sendai 980, Japan and *Department of Pharmacology, Akita University, \\ School of Medicine, Akita 010, Japan
}

Accepted February 19, 1980

\begin{abstract}
The effects of captopril administered intravenously in a dose of $1 \mathrm{mg} / \mathrm{kg}$ on systemic blood pressure (SBP), renal blood flow (RBF) and renal vascular resistance (RVR) were examined in pentobarbital anesthetized dogs. Untreated dogs were used in experiments in which the renal artery remained intact and others in which the renal artery was partially occluded (RAO). Captopril significantly decreased SBP, increased RBF and decreased RVR in untreated dogs. RAO induced an increase in arterial plasma renin activity and this increase was accompanied by an increase in RVR in the contralateral kidney and rise in SBP. During RAO, captopril induced qualitatively similar, but greater decreases in SBP and RVR of the contralateral kidney compared with those in the untreated dogs. These results suggest the vasodilator effect of captopril depends on the background level of angiotensin II and the enhanced effect would be expected under conditions such as RAO where circulating angiotensin II contributes to vascular tone.
\end{abstract}

The renal vasculature is particularly sensitive to the vasoconstrictor action of angiotensin II $(1,2)$. In hypertension and other conditions characterized by hypersecretion of renin, the renal vasoconstrictor effect of angiotensin II no doubt plays an important role. Endogenous angiotensin exerts an influence on renal vascular resistance in dogs with a vena caval occlusion or in those on a low-salt diet $(3,4)$.

The present study was an attempt to determine the effect of an acute rise in circulating renin, induced by partial renal artery occlusion, on blood pressure and contralateral renal vascular resistance. The resulting renal vascular changes were blocked by administration of captopril, an orally active converting enzyme inhibitor $(5,6)$.

\section{MATERIALS AND METHODS}

Sixteen dogs of either sex weighing 9 to $16 \mathrm{~kg}$ were anesthetized with sodium pentobarbital $(30 \mathrm{mg} / \mathrm{kg}$, i.v.) and artificially ventilated after giving decamethonium bromide $(0.25 \mathrm{mg} / \mathrm{kg}$, i.v.), a skeletal muscle relaxant. The animal was suspended from a metal frame by one of its spinous processes to facilitate manipulation of the renal vessels as reported previously (7). Eight untreated dogs were used in experiments in which the renal artery remained intact and eight others in experiments in which the renal artery was partially occluded (RAO). The left kidney of the untreated dogs or both kidneys in experiments 
involving RAO were exposed through a retroperitoneal incision. A blood flow probe ( 2.5 to $3 \mathrm{~mm}$ in diameter) was placed on the renal artery adjacent to the aorta and connected to an electromagnetic flowmeter (Nihon Kohden MF-27) to record the renal blood flow (RBF). In experiments involving RAO, an adjustable clamp was placed on one renal artery distal to the flow probe and was left open during the control period. The brachial artery was cannulated for measurement of mean systemic blood pressure (SBP) and blood was sampled for determination of plasma renin activity (PRA). The cephalic vein was cannulated to facilitate intravenous administrations. PRA in five $\mathrm{ml}$ samples of arterial blood was determined by radioimmunoassay of angiotensin I employing a kit purchased from Dainabott Labs. All samples were incubated at $37^{\circ} \mathrm{C}$ for $2 \mathrm{hr}$, and activity was expressed as $\mathrm{ng} \cdot \mathrm{ml}^{-1} \cdot \mathrm{hr}^{-1}$ in angiotensin $\mathrm{I}$.

In untreated animals, after allowing for stabilization of SBP and RBF, a control sample of arterial blood was taken for determination of PRA. Then, captopril at the dose of $1 \mathrm{mg} /$ $\mathrm{kg}$ was given intravenously. In experiments involving RAO, after sampling blood in the control period, a clamp was placed on one renal artery and tightened until blood flow was decreased by approx. $50 \%$ of the control value. Further adjustments of the clamp were made until a steady level of renal blood flow was attained in a manner similar to that reported previously (8). SBP and RBF of the "untouched" contralateral kidney stabilized during the period of 30 to $50 \mathrm{~min}$ after the start of RAO. Then, the second blood sample was withdrawn and captopril at the same dose of $1 \mathrm{mg} / \mathrm{kg}$ was given intravenously soon afterwards (2-3 min) during RAO. At the end of each experiment, the kidney was excised and weighed to calculate the values of RVR. The results are presented as the mean $\pm \mathrm{SE}$ in the text and table. Differences were considered significant at a level of $\mathrm{p}<0.05$, using Student's $t$-test for paired and unpaired data, respectively.

\section{RESULTS}

The effects of captopril on SBP, RBF and RVR are presented in Table 1. Values were obtained at $10 \mathrm{~min}$ after administration of captopril. In 8 untreated animals, PRA was $12.0 \pm 1.8 \mathrm{ng} \cdot \mathrm{ml}^{-1} \cdot \mathrm{hr}^{-1}$ and captopril induced a decrease in SBP of $19.4 \pm 4.0 \mathrm{~mm} \mathrm{Hg}$ ( $\mathrm{p}<0.001$ ), an increase in $\mathrm{RBF}$ of $19.0 \pm 5.5 \mathrm{ml} / \mathrm{min}(\mathrm{p}<0.02)$ or $15.8 \pm 3.8 \%(\mathrm{p}<0.02)$ and decrease in RVR of $9.0 \pm 0.5 \mathrm{~mm} \mathrm{Hg} / \mathrm{ml} / \mathrm{min} / \mathrm{g}(\mathrm{p}<0.001)$ or $27.7 \pm 3.0 \%(\mathrm{p}<0.001)$, respectively.

In the other 8 animals treated with RAO, the values of PRA, SBP, RBF and RVR were not statistically different from the corresponding values of the untreated animals during the control period. During the period of 30 to $50 \mathrm{~min}$ after the start of RAO, PRA was increased from the control value of $11.5-3.0 \mathrm{ng} \cdot \mathrm{ml}^{-1} \cdot \mathrm{hr}^{-1}$ to $29.7 \pm 3.2 \mathrm{ng} \cdot \mathrm{ml}^{-1} \cdot \mathrm{hr}^{-1}(\mathrm{p}<0.001)$, SBP was increased by $13.1 \pm 2.5 \mathrm{~mm} \mathrm{Hg}(\mathrm{p}<0.01)$, RBF was decreased in 6 out of 8 animals but was not significantly changed and RVR was increased by $6.7 \pm 2.1 \mathrm{~mm} \mathrm{Hg} / \mathrm{ml} / \mathrm{min} / \mathrm{g}$ $(\mathrm{p}<0.02)$ or $23.6 \pm 8.3 \%(\mathrm{p}<0.02)$. PRA during RAO was greater $(\mathrm{p}<0.01)$ than that of the untreated animals. However, the values of SBP, RBF and RVR during RAO prior to the administration of captopril were not significantly different from those of the untreated 


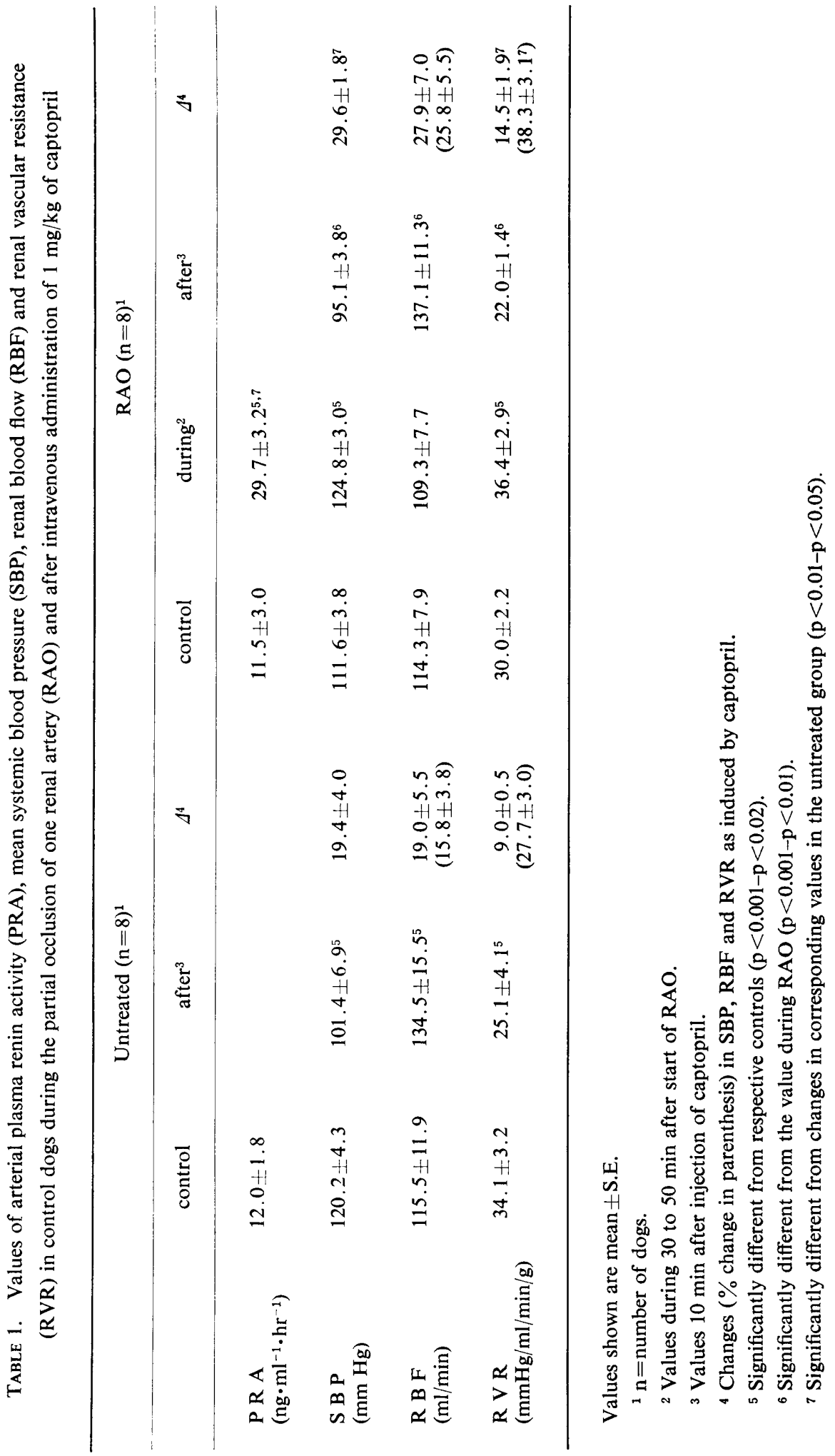


animals. During RAO, captopril induced a hypotensive effect of $29.6 \pm 1.8 \mathrm{~mm} \mathrm{Hg}$ ( $\mathrm{p}<0.001$ ), an increase in $\mathrm{RBF}$ of $27.9 \pm 7.0 \mathrm{ml} / \mathrm{min}(\mathrm{p}<0.01)$ or $25.8 \pm 5.5 \%(\mathrm{p}<0.01)$ and decrease in RVR of $14.5 \pm 1.9 \mathrm{~mm} \mathrm{Hg} / \mathrm{ml} / \mathrm{min} / \mathrm{g}(\mathrm{p}<0.001)$ or $38.3 \pm 3.1 \%(\mathrm{p}<0.001)$. The magnitude of changes in these values induced by captopril was greater in $\operatorname{SBP}(\mathrm{p}<0.05)$ and in RVR ( $\mathrm{p}<0.05$ for both absolute and \% changes) than those of the untreated animals. The mean increase in RBF induced by captopril during RAO was greater than that of the untreated animals, but the difference was not statistically significant.

\section{DISCUSSION}

Captopril decreased SBP and RVR, and increased RBF in the untreated animals. These observations were much the same as reported by Murthy et al. (9). The changes induced by captopril are attributed to two possible mechanisms. Barbiturate anesthesia activates the renin-angiotensin system in the dog (10-12), therefore endogenously generated angiotensin II may influence the resting SBP, RBF and RVR. Inhibition of the formation of angiotensin II with captopril would eliminate this influence and hypotension and decrease in renal vascular resistance would ensue. Another possibility is that the hypotension may be unrelated to blockade of the renin-angiotensin system (13).

During RAO, the elevated plasma renin level was associated with significant increments in SBP and RVR. This provides evidence for the influence of acute RAO in one kidney on RVR of the contralateral kidney. Under this condition captopril induced a greater reduction in SBP and RVR compared with that in the untreated dogs. This suggests that the vasodilator effect of captopril depends on the background level of angiotensin II, in other words, a greater effect would be expected under conditions in which circulating angiotensin II contributes to vascular tone, such as in RAO.

Converting enzyme also catalyzes the inactivation of kinins (14), and captopril enhances the hypotensive effect of bradykinin $(15,16)$. Therefore, the kinins may contribute to the effect of captopril. It has been reported that angiotensin II and a kinin-like substance appear in renal venous blood after reduction of renal blood flow (17). Therefore, it is probable that the interventions imposed on our animals may induce a simultaneous increase in the amounts of angiotensin II and kinins in the circulating blood. Whether the hypotensive and renal vascular effects of captopril are exerted by prevention of the formation of angiotensin II and/or by accumulation of endogenous kinins is now being investigated.

Our findings indicate that during acute partial renal artery occlusion, the release of renin through formation of angiotensin results in an increase in systemic blood pressure and renal vascular resistance in the contralateral kidney. Captopril induces a greater reduction in SBP and RVR after RAO than in untreated dogs, through the inhibition of formation of angiotensin II, and SBP and RVR are restored to a lower level.

Acknowledgements: We thank Squibb JAPAN Inc. for provision of captopril. This study was partially supported by a grant of Sankyo Central Laboratories. 


\section{REFERENCES}

1) McGiff, J.C. And Aviado, D.M.: Differential response of renal and femoral blood flows and vascular resistances. Hypotensive and hypertensive procedures. Circulation Res. 9, 1327-1335 (1961)

2) Assali, N.S. and Westersten, E.E.: Regional flow-pressure relationship in response to angiotensin in the intact dog and sheep. Circulation Res. 9, 189-193 (1961)

3) Johnson, J.A. AND Davis, J.O.: Effects of specific competitive antagonist of angiotensin II on arterial pressure and adrenal steroid secretion in dogs. Circulation Res. 32 Supp. I, I-159-I-168 (1973)

4) Johnson, J.A. and Davis, J.O.: Angiotensin II; important role in the maintenance of arterial blood pressure. Science 179, 906-907 (1973)

5) Ondetti, M.A., Rubin, B. ANd Cushman, D.W.: Design of specific inhibitors of angiotensinconverting enzyme : new class of orally active antihypertensive agents. Science 196, $441-444$ (1977)

6) Laffan, R.J., Goldberg, M.E., High, J.P., Schaeffer, T.R., Waugh, M.H. and Rubin, B.: Antihypertensive activity in rats of SQ 14,225 , an orally active inhibitor of angiotensin converting enzyme. J. Pharmacol. exp. Ther. 204, 281-288 (1978)

7) Satoh, S. ANd Zimmerman, B.G.: Effect of $\left[\mathrm{Sar}^{1}, \mathrm{Ala}^{8}\right]$ angiotensin II on renal vascular resistance. Am. J. Physiol. 229, 640-645 (1975)

8) SAToh, S. And Zimmerman, B.G.: Influence of renin-angiotensin system on effect of prostaglandin synthesis inhibitors in renal vasculature. Circulation Res. 36-37 Supp. I, I-89-I-98 (1975)

9) Murthy, V.S., WALDRON, T.L. AND GOLDBerG, M.E.: Inhibition of angiotensin-converting enzyme by SQ 14,225 in anesthetized dogs. : Hemodynamic and renal vascular effects. Proc. Soc. exp. Biol. Med. 157, 121-124 (1978)

10) Burger, B.M., Hopkins, T., Tulloch, A. And Hollenberg, N.K.: The role of angiotensin in the canine renal vascular response to barbiturate anesthesia. Circulation Res. 38, 196-202 (1976)

11) Johnson, M.D. And Malvin, R.L.: Plasma renin activity during pentobarbital anesthesia and graded hemorrhage in dogs. Am. J. Physiol. 229, 1098-1101 (1975)

12) GANONG, W.F.: Sympathetic effects on renin secretion; mechanism and physiological role. Advan. exp. Med. Biol. 17, 17-32 (1972)

13) Vollmer, R.R., Boccagno, J.A., Harris, D.N. and Murthy, V.S.: Hypotension induced by inhibition of angiotensin-converting enzyme in pentobarbital-anesthetized dogs. Europ. J. Pharmacol. 51, 39-45 (1978)

14) Erdös, E.G.: The angiotensin I converting enzyme. Fedn. Proc. 36, 1760-1765 (1977)

15) Murthy, V.S., Waldron, T.L., GoldberG, M.E. and Vollmer, R.R.: Inhibition of angiotensin converting enzyme by SQ 14,225 in conscious rabbits. Europ. J. Pharmacol. 46, 207-212 (1977)

16) Rubin, B., Laffan, R.J., Kotler, D.G., O’Keffe, E.H., DeMalo, D.A. and Goldberg, M.E.: SQ 14,225 (D-3-mercapto-2-methylpropanoyl-L-proline), a novel orally active inhibitor of angiotensin I-converting enzyme. J. Pharmacol, exp. Ther. 204, 271-280 (1978)

17) NG, K.K.F.: Generation of kinin by renin, Prostaglandins, Peptides and Amines, Edited by Mantegazz.A, P. and Horton, E.W., p. 9-13, Academic Press, New York (1969) 